\title{
Carbon Polygons and Carbon Offsets: Current State, Key Challenges and Pedological Aspects
}

\author{
Evgeny Abakumov*(D) and Vyacheslav Polyakov (iD \\ Department of Applied Ecology, Faculty of Biology, Saint Petersburg State University, Universitetskaya nab., 7-9, \\ 199034 Saint Petersburg, Russia; slavon6985@gmail.com \\ * Correspondence: e.abakumov@spbu.ru or e_abakumov@mail.ru
}

\begin{abstract}
Russia holds the largest store of carbon in soils, forests and permafrost grounds. Carbon, stored in a stabilized form, plays an important role in the balance of the global biogeochemical cycle and greenhouse gases. Thus, recalcitrance of soil organic matter to mineralization results in a decrease in current emissions of carbon dioxide into the atmosphere. At the same time, stabilization of organic matter in the form of humus due to organo-mineral interactions leads to the sequestration of carbon from the atmosphere into soils and biosediments. Thus, global carbon balance is essentially determined by soil cover state and stability. Currently, Russia is faced with a set of problems regarding carbon offsets and the carbon economy. One of the methods used to evaluate carbon stocks in ecosystems and verify offsets rates is carbon polygons, which are currently being organized, or are under organization, in various regions of Russia. This discussion addresses the current issues surrounding the methods and methodology of carbon polygons and their pedological organization and function.
\end{abstract}

check for updates

Citation: Abakumov, E.; Polyakov, V. Carbon Polygons and Carbon Offsets: Current State, Key Challenges and Pedological Aspects. Agronomy 2021, 11, 2013. https://doi.org/10.3390/ agronomy11102013

Academic Editor: Bhupinder Pal Singh

Received: 25 August 2021

Accepted: 3 October 2021

Published: 7 October 2021

Publisher's Note: MDPI stays neutral with regard to jurisdictional claims in published maps and institutional affiliations.

Copyright: (c) 2021 by the authors. Licensee MDPI, Basel, Switzerland. This article is an open access article distributed under the terms and conditions of the Creative Commons Attribution (CC BY) license (https:// creativecommons.org/licenses/by/ $4.0 /)$.
Keywords: carbon polygons; carbon sequestration; climate change; carbon balance; soil organic matter

\section{Introduction}

Soil organic carbon (SOC) is the main component of soil organic matter (SOM) [1,2]. SOC can be assumed as an indicator of soil health and plays a critical role in food production, climate change and sustainable human development [3,4]. In the face of climate change, $\mathrm{SOC}$ can be mineralized faster and become a significant source of greenhouse gases in the atmosphere $[5,6]$. However, the overall impact of climate change on SOC content differs depending on region and soil type [7-12]. Climate change can have catastrophic consequences for SOC and soils [2,4,9]. As a result, we can observe land degradation in various areas of the planet (the Arctic, desert and mountainous zones) [3,13-15]. Today, the world's soil contains up to $1500 \mathrm{Pg}\left(1 \times 10^{15} \mathrm{~g}\right)$ of soil organic carbon in the upper meter horizon $[3,4,16]$. The soil with the richest SOC levels (Histosol and Chernozem), as well as drylands with low carbon content, have the potential to make the greatest contribution to climate change [9]. The areas occupied by permafrost-affected soils make up more than 8.6 million $\mathrm{km}^{2}$, roughly $27 \%$ of all land north of $50^{\circ} \mathrm{N}$, meaning that up to $1024 \mathrm{Pg}$ of soil organic carbon is stored within the upper $3 \mathrm{~m}$ of soil $[1,17]$. Thus, the management of these territories can enhance the sequestration of carbon in soils, contributing to the mitigation of climate change on our planet [2-4,9].

The soil cover of Russia holds the largest store of carbon in the whole world and is the most important area for carbon deposition in the northern hemisphere. Carbon stock in soils and biosediments have been evaluated by numerous investigators $[4,7,9,12,14]$. During the Postsoviet era, the sequestration rate of carbon in soil increased sharply due to abandoning of millions of hectares of arable lands and afforestation of former agricultural lands $[18,19]$. Thus, the abandoned agricultural lands were formed in various bioclimatic environments, and have recently been used for retrospective analyses of soil parameters by numerous researchers [20-24]. In this context, the forthcoming plans regarding the creation 
of special monitoring plots state that carbon polygons should be considered and discussed in terms of pedological methodology with the aim of mutualizing carbon poll assessments with carbon offset risks in our national environmental economy and carbon market.

Carbon polygons are places where carbon dioxide emissions and accumulation are monitored under conditions of various types of relief and soil cover [4] (Figure 1).

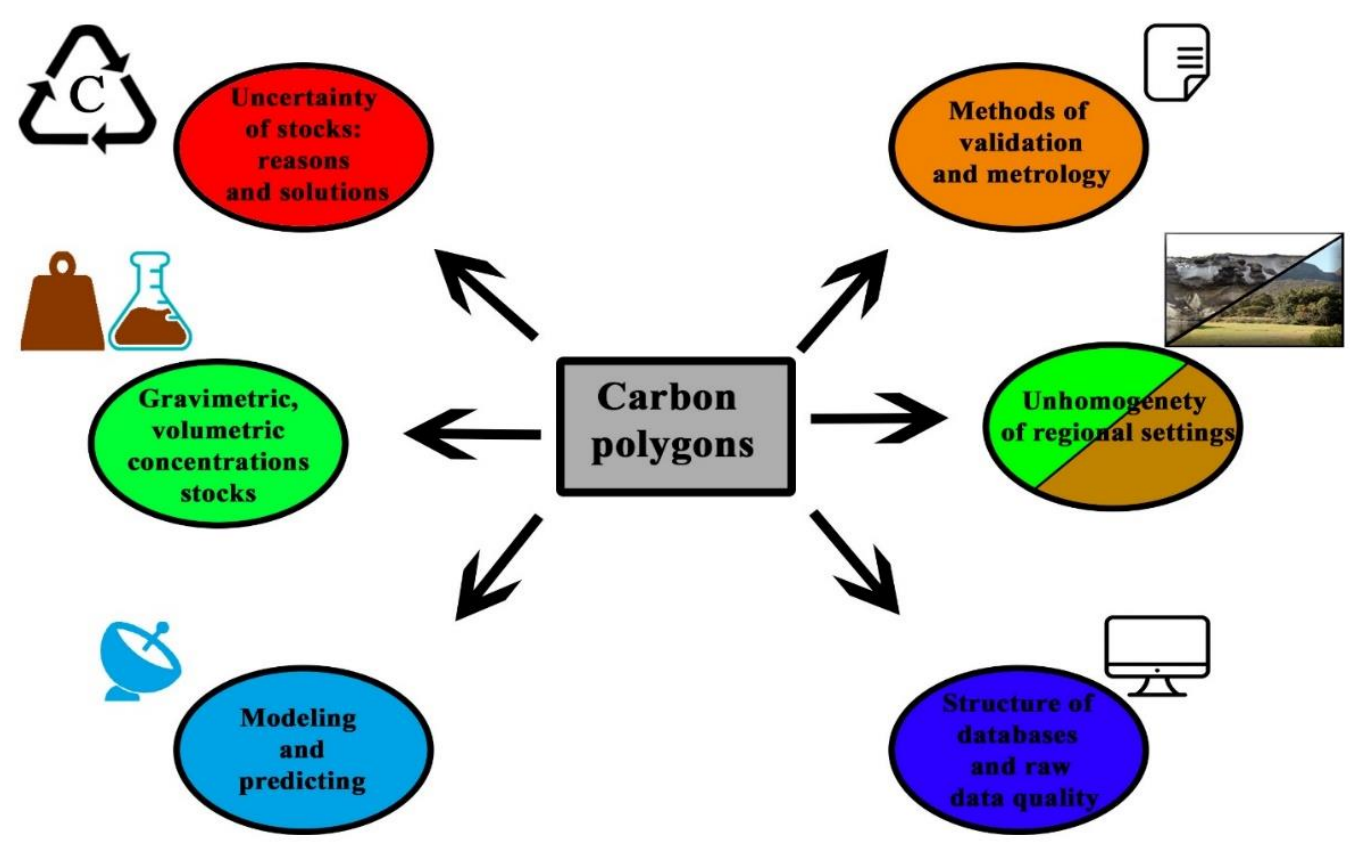

Figure 1. Responsibility tasks of carbon polygons.

Today, Russia has the only "Ugra" carbon polygon it located in the Kaluga region, which is a place for studying the global carbon balance and sequestration potential of the territory (Figure 2). It is planned to create polygons in Kaliningrad, Krasnodar, Sverdlovsk, Tyumen, Novosibirsk and Sakhalin regions as well as Chechen and Tatarstan republic up to 2022. Thus, the formation of carbon polygons in Russia will allow for the creation of a monitoring network that will study the processes of formation, accumulation, emission and deposit of priority greenhouse gases in various ecosystems of our country $[25,26]$. When forming carbon polygenes in natural zonal environments, industrial areas, large cities and anthropogenic ecosystems, it will create a reliable and productive monitoring network that will contribute to the study of the planetary carbon cycle and sequestration potential of the territory of the Russian Federation. This will allow to Russia to comply with the goals set out in the Sustainable Development Cooperation Framework of the UN and the Paris Climate Agreement $[27,28]$. 


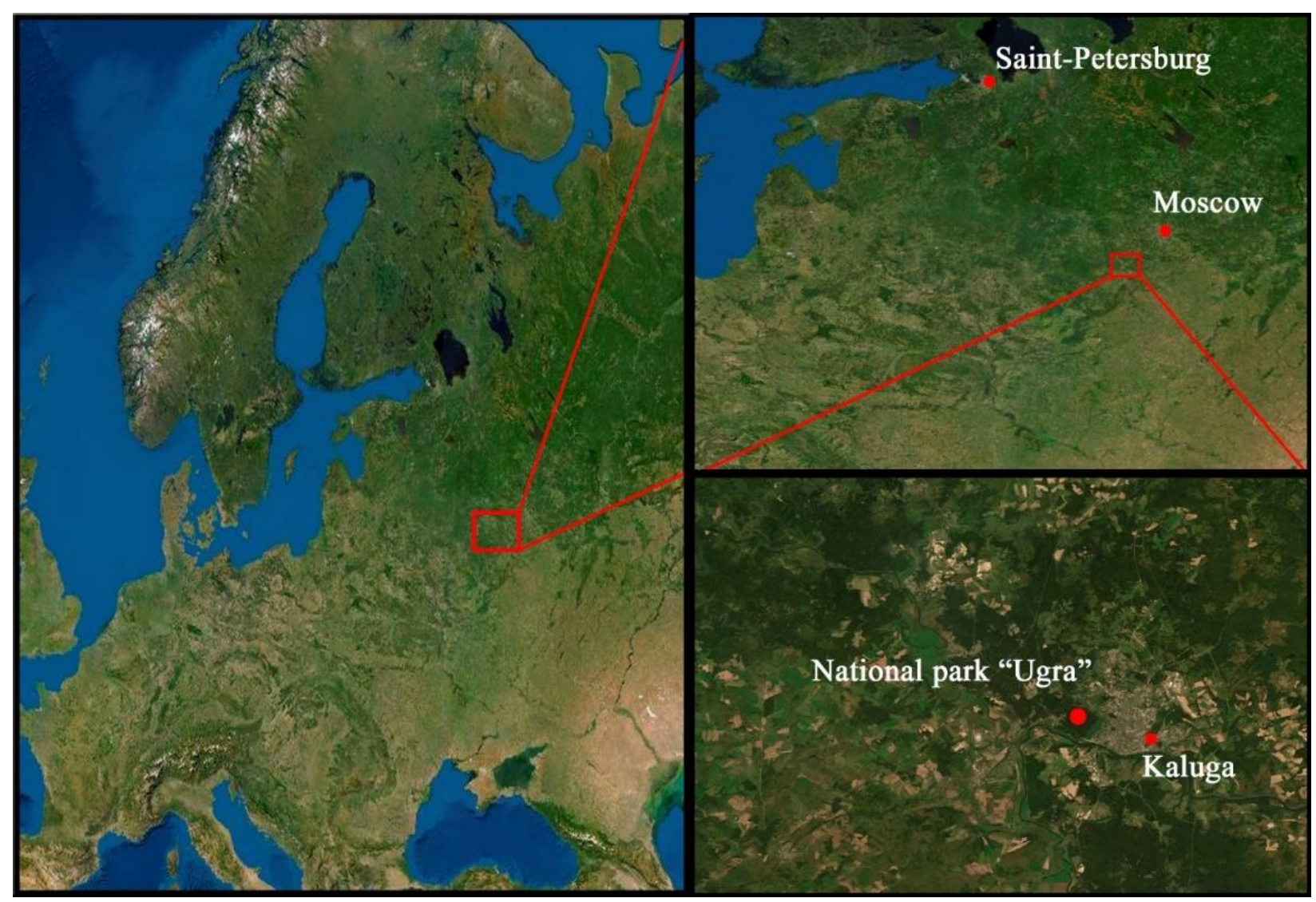

Figure 2. First carbon polygon in Russia. National park "Ugra" (Source: ESRI: Geographic information system company (West Redlands, California, United States of America)).

\section{Carbon Polygons: Current State and Key Challenges}

\subsection{Carbon Input and Emission}

The input of carbon into soil is determined by two flows: aboveground and belowground. The first can be measured by a monthly quantification of litterfall in litter traps, which is quite useful when calculating carbon balance [29]. Below ground input is less costly in terms of time but more difficult to count the living-root biomass. As for the total emission of $\mathrm{CO}_{2}$, the classic method of closed field chambers [30] or the more advanced eddy covariance method are appropriate. The eddy covariance method is based on the measurement of net exchange of $\mathrm{CO}_{2}$ over study area, as well as wind speed, to provide data regarding changes in SOC stocks [4]. The closed field chamber method is manual; therefore, portable $\mathrm{CO}_{2}$ measurement units can be quickly transported and installed at the studied sites. This method is cheap and provides a simple analysis when investigating the carbon budget in an ecosystem, but it cannot cover a large area of investigation sites. Therefore, using the eddy covariance method is the most appropriate option for analyzing a carbon budget. The eddy covariance method allows dynamic data retrieval from a specific carbon landfill over a long period in any conditions (Arctic, Boreal, Tropical, etc.). For the placement of an eddy covariance tower, certain conditions must be observed, such as stable conditions for the polygons (wind, temperature, humidity and $\mathrm{CO}_{2}$ ), homogeneity of the vegetation cover, as well as flat terrain [31]. It can cover an area of up to several hectares. However, this method is highly specialized and expensive. The use of this method depends on a number of local conditions: wind speed and direction, stable turbulent flow and the homogeneous distribution of the source and sink of $\mathrm{CO}_{2}[4]$. 
An important stage in this process is the task monitoring carbon dioxide and methane emissions in the Arctic sector of the Russian Federation. In the Russian Arctic, there are a number of monitoring stations (subordinated to the state monitoring network of Rosgidromet), which monitor greenhouse gas emissions, as well as the climatic parameters of remote territories. Such centers are located on the Svalbard Archipelago (Barentsburg), the Severnaya Zemlya Archipelago (Cape Baranova), a climate station in Tiksi (Yakutia), as well as a station on Samoilovsky Island (Yakutia). The soil of the circumpolar area (Histosols, Cryosols) is a potential hot spot for greenhouse gases. A significant amount of soil organic carbon is stored here, which can be further involved in the global carbon cycle and significantly contribute to climate change on the planet $[1,32,33]$. During the thawing of permafrost, greenhouse gases $\left(\mathrm{CO}_{2}, \mathrm{CH}_{4}\right)$ are emitted. One example is the Lena River Delta (Yakutia), where $\mathrm{CO}_{2}$ emissions of up to $58.6 \mathrm{~g} \mathrm{CO}_{2}-\mathrm{C} \mathrm{kgC}^{-1}$ were observed in oxic conditions, while in anoxic areas, these figures were $17.5 \mathrm{~g} \mathrm{CO}_{2}-\mathrm{C} \mathrm{kgC}^{-1}$ and $10.7 \mathrm{~g} \mathrm{CH}_{4}-\mathrm{C} \mathrm{kgC}^{-1}$. Under the conditions of climate change, based on the current forecast, greenhouse gas emissions could increase to $113 \mathrm{~g} \mathrm{CO}_{2}-\mathrm{C} \mathrm{kgC}^{-1}$ in oxic conditions and up to $241 \mathrm{~g} \mathrm{CO}_{2}$-Ce (carbon equivalents) $\mathrm{kgC}^{-1}$ in anoxic conditions by the year 2100 [34]. Thus, an important task is to monitor the most vulnerable ecosystems in order to calculate their possible contribution to climate change. We suggest that at least two carbon polygons should be located in the cryogenic ecosystems of Russia.

\subsection{Carbon in the Fine Earth: Direct or Indirect}

The most important area of study concerning carbon polygons is the problem of assessing the reserves and trends in the stability of organic matter in the soil of natural ecosystems. An adequate assessment of these stocks should be based on verified methods for determining the content of organic matter (direct and indirect methods and the problem of the correlation of results) and on unified ideas about the depth and regularity of sampling within soil profiles and monitoring sites. This problem is particularly relevant to the development of a spatial network of carbon polygons in the Russian Federation. Currently, two methods are used for the determination of gravimetric concentrations of soil organic carbon. The first is based on direct dry combustion of the carbon and an evaluation of the $\mathrm{CO}_{2}$ emitted [35-38]. This method is very precise and accurate, but not every laboratory in Russia has the opportunity to work with these analyzers. Small laboratories cannot afford the purchase and maintenance of such equipment. In contrast, the indirect oxidation methods of Tyurin (Central and Eastern European countries) and Walkley-Black (Western world) [30,38], are based on the oxidation of carbon, halogens, Fe ions and can be easily implemented in any laboratory. These methods are also economically viable, with roughly $97 \%$ of all data on soil and sediments carbon content being retrieved by these methods. However, these methods are inaccurate in many cases and do not work on salinized soils, soils with a high content of aliphatic chains in organic matter [38], and soils with a high iron content. Comparing this to previous data we have, these are indirect oxidation data [37,38]. In the context of the new contemporary polygons, it is necessary to decide, at the very beginning, which method we will use.

\subsection{Gravimetric and Volumetric Concentration of Carbon}

If gravimetric determination of carbon in fine earth is more or less clear, the conversion methods of gravimetric rates to volumetric concentrations or stocks are far from a complete resolution $[1,39]$. If soil density is usually considered, its rockiness is very rare, and the supply of organic substances greatly depends on this. Considering that the world's share of rocky and skeletal soils has reached $30 \%$, this is an important methodological issue $[3,4,40]$. Therefore, an important task is the development of a unified system for determining the carbon content in soil and its stocks, depending on regional settings. 


\subsection{Humus Forms and Sampling of Soil Organic Profile}

In Russia, different concepts are used regarding soil organic matter and humus compared to the EU and the USA. In the EU and USA, the SOM includes the following fractions: plant residues, particle decomposed plant materials, soil microbial biomass and humus [4]. In Russian pedology, humus is often understood as a colloidal organic substance that consists of humic acids and the precursors of humification (proteins, carbohydrates, lignin and aldehydes). Organic residues presented in the form of peat, sapropel, plant litter and organic fertilizers are not considered humus in the Russian School of Soil Science [41,42]. This is why, when determining carbon in fine earth, roots and detritus forms of organic matter are extracted, a process that is not always practiced in the EU and USA. Therefore, the concepts of humus, soil organic matter and total organic carbon, are not equivalent $[43,44]$. The concept of "carbon of organic compounds" also differs from them. Thus, we have to decide what we will use for monitoring and from which horizons we will gather regular samples, e.g., are we going to include a forest floor or all superficial undecomposed organic matter, which is an important part of stock [43,45-48] but not stabilized? The sequestration of organic carbon occurs at various levels of organization of organic matter, in forest litter, in peat and in the organo-mineral and mineral horizons. Due to various stabilization mechanisms (mechanical, chemical and molecular), SOM is transformed into a more stable form and can be stored in a soil for a long time [14,49]. Another important question is related to sampling depth: 0-20 (arable layers), 0-100 (the average depth of soil in Eurasia) or the horizontal approach (sampling form each soil genetic horizon). Thus, we have numerous key questions on sampling strategy that we must discuss and define at the very beginning of polygon creation.

\subsection{Polygons in Space and Regional Settings}

Currently, carbon polygons proposed by the Ministries of Education and Science in the Russian Federation [50] do not cover all natural zones. The proposed approach is based on the location of polygons in different areas of the Russian Federation. However, not all of the natural conditions, even at the biome level, will be covered by the proposed network of polygons, which will lead to distortions and inaccuracies even in approximate assessments. The planned network of carbon polygons does not yet include cryogenic soils found in of the circumpolar environments, in which huge reserves of organic matter are concen trated. It is necessary to pay special attention to the need to expand the network of carbon polygons to all natural zones of Russia. Russian boreal soil, polar soil and subsurface sediments possess the highest stock of carbon in the northern hemisphere; nevertheless, the stocks of organic matter in these environments are underestimated due to the complex heterogeneity of the territory and the presence of permafrost tables on soil [1]. Thus, the question of covering the country with the polygons is a keynote for the accurate assessment of carbon stocks, taking into account the unique phenomena of soils and environment zonality, which has been elaborated by V.V. Dokuchaev [41]. If Russia follows a zonal approach in the spatial distribution of polygons, it will become a standard for the whole world-all types of biomes will be covered, except for tropical ones. In this context, the previous experience of the International Biological Program should also be obtained [51,52]. The soils of Russia, taking into account the greatest pedodiversity, should be a standard in terms of humus state and carbon content metrology (Figure 3). 


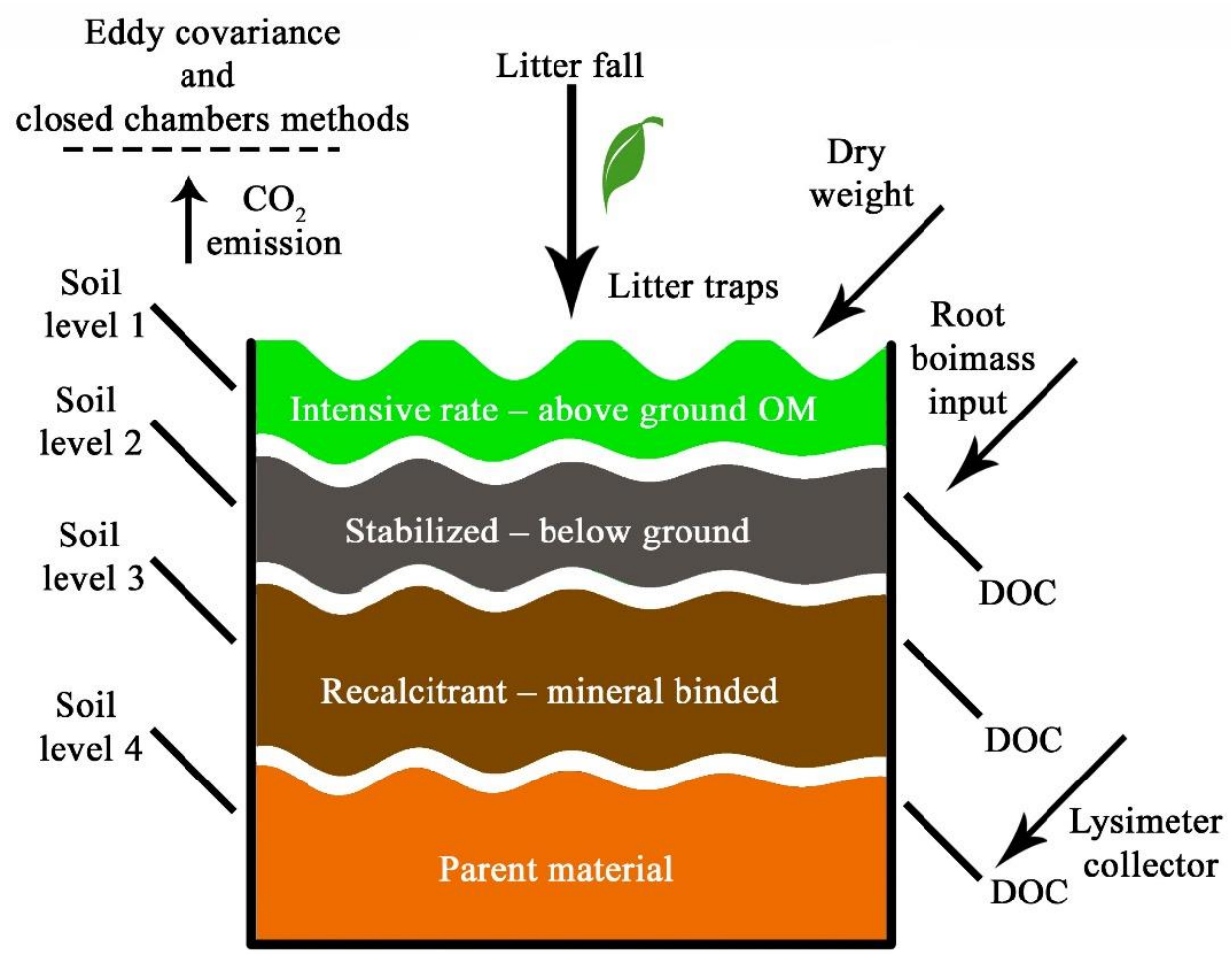

Figure 3. Schematic structure of carbon polygons functions and methods of carbon traps.

\subsection{Modeling and Predicting}

Modeling is a critical tool for predicting and analyzing large amounts of data, including carbon data. Modern mathematical simulation models (Romul, Efimod) allow one to process large amounts of soil-climatic and soil-chemical data to predict the dynamics of the content of various fractions of organic matter, from easily decomposable to highly stabilized $[43,45,46,48]$. Soil-climatic data are currently in deficit; therefore, a long-term temperature and water content logger should be inserted into the soil, at different depths to provide an automatic meteostation on the soil's surface. High-accuracy simulation modeling is not only important from the point of view of basic science; it is also important for the forecasting markets of carbon units and carbon offsets. Every type of carbon market should be targeted by a prediction system, such as a mathematical simulation model. This model should be verified using the input data derived from carbon polygons. The use of GIS systems is also crucial for the generalization of big raw data and the visualization of boundless information [51,52].

\subsection{Carbon Offsets}

"Stock or source?"- -this is a key question concerning carbon polygons methodology. Can any natural zone of Russia represent the carbon sequestration-stock formation zone? Are any of these zones and environments critically important in terms of anthropogenically derived $\mathrm{CO}_{2}$ emissions? How can we manage carbon fluxes to reduce emissions, increase sequestration and redistribute these components within the time and space available [53-55]? Another question-is decision making based on scientific data derived from polygons and environmental management practices in the fields of forestry, agronomy, mining and industry. Despite these questions, one of the most important tasks is understanding the rate at which organic carbon can be evaluated and assessed in terms of an ecosystem services evaluation. Here, both the stock (volumetric concentration), and the quality of organic matter (stabilization rate and resistance to mineralization) should play a crucial role [56,57]. The final inquiry of this discussion is "whether the carbon unit of humus of one quality is comparable to the carbon unit of humus of another quality?". In other words, is 1 ton of Chernozemic carbon comparable to 1 ton of organic carbon derived from 
Podzol? The above questions are not pedological, but relate to environmental economics and the monetization of ecosystem services (carbon units market), an area that is far from resolved [58,59]. As a result of increased anthropogenic activity in these natural ecosystems, the carbon balance within these territories becomes violated. The utilization of carbon polygons will make it possible to control Russia's carbon balance and monitor climate change in various geographic and climatic conditions within one country.

\section{Conclusions}

While creating the carbon polygon in any part of a country, we should discuss: (1) terminology - what we are determining, how and where, e.g., sampling strategy, laboratory processing, the transfer from a gravimetric to a volumetric concentration of carbon and related biogenic elements; (2) the spatial coverage of Russia by polygons and regional setting: we have to avoid the effects of data clusterization for better future spatial and temporal data interpolation; (3) vertical frequency and temporal regularity of sampling: data from different deeps and different season are not comparable in terms of monitoring; (4) how to store/process raw data and how to generalize the great data massive? and, the last but nevertheless important question; (5) obviously, the carbon unit itself depends on how to measure it and how to calculate it, and whether the equivalent of the carbon currency will depend on our methodology and how we organize the network of carbon polygons.

Author Contributions: Conceptualization, E.A. and V.P.; writing-review and editing, E.A. and V.P. All authors have read and agreed to the published version of the manuscript.

Funding: This work was supported by Federal budget of Russian Federation, grant for support for the creation and development of a World -class Scientific Center "Agrotechnologies for the Future", project No. 075-15-2020-922.

Institutional Review Board Statement: Not applicable.

Informed Consent Statement: Not applicable.

Data Availability Statement: Not applicable.

Conflicts of Interest: The authors declare no conflict of interest.

\section{References}

1. Zubrzycki, S.; Kutzbach, L.; Pfeiffer, E.-M. Permafrost-affected soils and their carbon pools with a focus on the Russian Arctic. Solid Earth 2014, 5, 595-609. [CrossRef]

2. Schuur, E.A.G.; McGuire, A.D.; Schadel, C.; Grosse, G.; Harden, J.W.; Hayes, D.J.; Hugelius, G.; Koven, C.D.; Kuhry, P.; Lawrence, D.M.; et al. Climate change and the permafrost carbon feedback. Nature 2015, 520, 171-179. [CrossRef]

3. Lefèvre, C.; Rekik, F.; Alcantara, V.; Wiese, L. Soil Organic Carbon: The hidden potential; Food and Agriculture Organization of the United Nations: Rome, Italy, 2017.

4. Leap, F. Measuring and Modelling Soil Carbon Stocks and Stock Changes in Livestock Production Systems: Guidelines for Assessment (Version 1). Livestock Environmental Assessment and Performance (LEAP) Partnership; FAO: Rome, Italy, 2019; p. 170.

5. Knoblauch, C.; Beer, C.; Sosnin, A.; Wagner, D.; Pfeiffer, E.-M. Predicting long-term carbon mineralization and trace gas production from thawing permafrost of Northeast Siberia. Glob. Chang. Biol. 2013, 19, 1160-1172. [CrossRef] [PubMed]

6. Abakumov, E.V.; Polyakov, V.; Orlova, K.S. Podzol development on different aged coastal bars of Lake Ladoga. Vestnik Tomsk. Gos. Univ. Biol. 2019, 48, 6-31. [CrossRef] [PubMed]

7. Beyer, L.; Sorge, C.; Blume, H.-P.; Schulten, H.-R. Soil organic matter composition and transformation in gelic histosols of coastal continental Antarctica. Soil Biol. Biochem. 1995, 27, 1279-1288. [CrossRef]

8. Dobrovolsky, G. Soils of the Floodplains of the Center of the Russian Plain; Moscow University Press: Moscow, Russia, 2005.

9. Davidson, E.A.; Janssens, I.A. Temperature sensitivity of soil carbon decomposition and feedbacks to climate change. Nature 2006, 440, 165-173. [CrossRef] [PubMed]

10. Okoneshnikova, M. Current state and prediction of changes in soils of the middle Lena valley (Central Yakutia). Tomsk. State Univ. J. Biol. 2013, 3, 7-18.

11. Lodygin, E.D.; Beznosikov, V.A.; Vasilevich, R.S. Molecular composition of humic substances in tundra soils (13C-NMR spectroscopic study). Eurasian Soil Sci. 2014, 47, 400-406. [CrossRef]

12. Alekseev, I.; Abakumov, E. Permafrost-affected former agricultural soils of the Salekhard city (Central part of Yamal region). Czech Polar Rep. 2018, 8, 119-131. [CrossRef] 
13. Becker, T.; Kutzbach, L.; Forbrich, I.; Schneider, J.; Jager, D.; Thees, B.; Wilmking, M. Do we miss the hot spots?-The use of very high resolution aerial photographs to quantify carbon fluxes in peatlands. Biogeosciences 2008, 5, 1387-1393. [CrossRef]

14. Ejarque, E.; Abakumov, E. Stability and biodegradability of organic matter from Arctic soils of Western Siberia: Insights from 13C-NMR spectroscopy and elemental analysis. Solid Earth 2016, 7, 153-165. [CrossRef]

15. Abakumov, E.; Maksimova, E.; Tsibart, A. Assessment of postfire soils degradation dynamics: Stability and molecular composition of humic acids with use of spectroscopy methods. Land Degrad. Dev. 2017, 29, 2092-2101. [CrossRef]

16. Muñoz-Rojas, M.; Jordán, A.; Zavala, L.M.; De la Rosa, D.; Abd-Elmabod, S.K.; Anaya-Romero, M. Organic carbon stocks in Mediterranean soil types under different land uses (Southern Spain). Solid Earth 2012, 3, 375-386. [CrossRef]

17. Gao, Y.; Couwenberg, J. Carbon accumulation in a permafrost polygon peatland: Steady long-term rates in spite of shifts between dry and wet conditions. Glob. Chang. Biol. 2015, 21, 803-815. [CrossRef] [PubMed]

18. Chestnykh, O.; Zamolodchikov, D.; Utkin, A.; Korovin, G. Distribution of organic carbon pools in soils of Russian Forests. Lesovedenie 1999, 2, 13-21.

19. Ivanov, A.; Stolbovoy, V. The initiative "4 per mille"-A new global challenge for the soils of Russia. Bull. VV Dokuchaev. Soil Sci. Inst. 2019, 98, 185-202. [CrossRef]

20. Khitrov, N.B. An approach for a retrospective assessment of soil changes. Eurasian Soil Sci. 2008, 41, 793-804. [CrossRef]

21. Karelin, D.V.; Goryachkin, S.V.; Kudikov, A.V.; De Gerenu, V.O.L.; Lunin, V.N.; Dolgikh, A.V.; Lyuri, D.I. Changes in carbon pool and $\mathrm{CO}_{2}$ emission in the course of postagrogenic succession on gray soils (Luvic Phaeozems) in European Russia. Eurasian Soil Sci. 2017, 50, 559-572. [CrossRef]

22. Kudeyarov, V.N. Soil-biogeochemical aspects of arable farming in the russian federation. Eurasian Soil Sci. 2019, 52, 94-104. [CrossRef]

23. Abakumov, E.; Morgun, E.; Pechkin, A.; Polyakov, V. Abandoned agricultural soils from the central part of the Yamal region of Russia: Morphology, diversity, and chemical properties. Open Agric. 2020, 5, 94-106. [CrossRef]

24. Ryzhova, I.M.; Telesnina, V.M.; Sitnikova, A.A. Dynamics of soil properties and carbon stocks structure in postagrogenic ecosystems of southern taiga during natural reforestation. Eurasian Soil Sci. 2020, 53, 240-252. [CrossRef]

25. Schepaschenko, D.G.; Mukhortova, L.V.; Shvidenko, A.Z.; Vedrova, E.F. The pool of organic carbon in the soils of Russia. Eurasian Soil Sci. 2013, 46, 107-116. [CrossRef]

26. Morkovina, S.; Panyavina, E.; Shanin, I.; Avdeeva, I. Economic aspects of the organization of carbon farms on forest site. Actual Dir. Sci. Res. Xxi Century: Theory Pract. 2021, 9, 17-26. [CrossRef]

27. Babenko, M.; Bobulev, A.; Bokarev, V. Sustainable Development of the UN and Russia Federation; Analytical center of Russia: Moscow, Russia, 2016; p. 44.

28. United Nations. Paris Agreement; United Nations: Paris, France, 2015.

29. Bazilevich, N.; Titlyanova, A. Biotic cycle on five continents: Nitrogen and ash elements in natural terrestrial ecosystems. Publishing House of SB RAS: Novosibirsk, Russia, 2008.

30. Carter, M.R.; Gregorich, E.G. Soil Sampling and Methods of Analysis; CRC Press: Boca Raton, FL, USA, 2007.

31. Baldocchi, D.D. Assessing the eddy covariance technique for evaluating carbon dioxide exchange rates of ecosystems: Past, present and future. Glob. Chang. Biol. 2003, 9, 479-492. [CrossRef]

32. Jongejans, L.L.; Liebner, S.; Knoblauch, C.; Mangelsdorf, K.; Ulrich, M.; Grosse, G.; Tanski, G.; Fedorov, A.N.; Konstantinov, P.Y.; Windirsch, T.; et al. Greenhouse gas production and lipid biomarker distribution in Yedoma and Alas thermokarst lake sediments in Eastern Siberia. Glob. Chang. Biol. 2021, 27, 2822-2839. [CrossRef]

33. Zubrzycki, S.; Kutzbach, L.; Grosse, G.; Desyatkin, A.; Pfeiffer, E.-M. Organic carbon and total nitrogen stocks in soils of the Lena River Delta. Biogeosciences 2013, 10, 3507-3524. [CrossRef]

34. Knoblauch, C.; Beer, C.; Liebner, S.; Grigoriev, M.N.; Pfeiffer, E.-M. Methane production as key to the greenhouse gas budget of thawing permafrost. Nat. Clim. Chang. 2018, 8, 309-312. [CrossRef]

35. Shahbazi, K.; Marzi, M.; Tabakhian, S. Comparative evaluation of methods for determining humus in soils. Eurasian Soil Sci. 1993, 9, 119-123.

36. Bhatti, J.S.; Apps, M.J.; Tarnocai, C. Estimates of soil organic carbon stocks in central Canada using three different approaches. Can. J. For. Res. 2002, 32, 805-812. [CrossRef]

37. Abakumov, E.V.; Popov, A.I. Determination of the carbon and nitrogen contents and oxidizability of organic matter and the carbon of carbonates content in one soil sample. Eurasian Soil Sci. 2005, 38, 165-172.

38. Polyakov, V.; Saint Petersburg State University; Orlova, K.; Abakumov, E. Evaluation of carbon stocks in the soils of Lena River Delta on the basis of application of "dry combustion" and Tyurin's methods of carbon determination. Biol. Commun. 2017, 62, 67-72. [CrossRef]

39. Hugelius, G.; Strauss, J.; Zubrzycki, S.; Harden, J.; Schuur, E.; Ping, C.-L.; Schirrmeister, L.; Grosse, G.; Michaelson, G.; Koven, C.; et al. Estimated stocks of circumpolar permafrost carbon with quantified uncertainty ranges and identified data gaps. Biogeosciences. 2014, 11, 6573-6593. [CrossRef]

40. WRB, I.W.G. World Reference Base for Soil Resources 2014, Update 2015; World Soil Resources Reports 106; FAO: Rome, Italy, 2015.

41. Orlov, D. Soil Humic Acids and General Theory of Humification; Moskowskowo Uniwersiteta: Moskwa, Russia, 1990 ; p. 325.

42. Orlov, D.S. Soil Chemistry; AA Balkema Publishers: Rotterdam, The Netherlands, 1992. 
43. Chertov, O.; Nadporozhskaya, M. Development and application of humus form concept for soil classification, mapping and dynamic modelling in Russia. Appl. Soil Ecol. 2018, 123, 420-423. [CrossRef]

44. Zanella, A.; Ponge, J.-F.; Gobat, J.-M.; Juilleret, J.; Blouin, M.; Aubert, M.; Chertov, O.; Rubio, J.L. Humusica 1, article 1: Essential bases-Vocabulary. Appl. Soil Ecol. 2018, 122, 10-21. [CrossRef]

45. Chertov, O.; Komarov, A.; Nadporozhskaya, M.; Bykhovets, S.; Zudin, S. Romul—A model of forest soil organic matter dynamics as a substantial tool for forest ecosystem modeling. Ecol. Model. 2001, 138, 289-308. [CrossRef]

46. Nadporozhskaya, M.A.; Chertov, O.G.; Bykhovets, S.S.; Shaw, C.H.; Maksimova, E.Y.; Abakumov, E.V. Recurring surface fires cause soil degradation of forest land: A simulation experiment with the EFIMOD model. Land Degrad. Dev. 2018, 29, 2222-2232. [CrossRef]

47. Shanin, V.N.; Bykhovets, S.S.; Chertov, O.G.; Komarov, A.S. The effect of various external factors on dynamics of organic carbon in different types of forest: A simulation-based assessment. Russ. J. For. Sci. 2018, 2018, 335-346. [CrossRef]

48. Priputina, I.V.; Bykhovets, S.S.; Frolov, P.V.; Chertov, O.G.; Kurganova, I.N.; De Gerenyu, V.O.L.; Sapronov, D.V.; Mjakshina, T.N. Application of mathematical models romul and romul_hum for estimating $\mathrm{CO}_{2}$ emission and dynamics of organic matter in albic luvisol under deciduous forest in the south of moscow oblast. Eurasian Soil Sci. 2020, 53, 1480-1491. [CrossRef]

49. Vasilevich, R.; Lodygin, E.; Beznosikov, V.; Abakumov, E. Molecular composition of raw peat and humic substances from permafrost peat soils of European Northeast Russia as climate change markers. Sci. Total. Environ. 2018, 615, 1229-1238. [CrossRef]

50. Decree of Ministry of Education and Science of Russian Federation. In On Landfills for the Development and Testing of Technologies for Monitoring Carbon Balance; Ministry of Education and Science of Russian Federation: Moscow, Russia, $2021 ; 17$ p.

51. Kudryashova, S.Y.; Baikov, K.S.; Titlyanova, A.A.; Dits, L.Y.; Kosykh, N.P.; Makhatkov, I.D.; Shibareva, S.V. Distributed GIS for estimation of soil carbon stock of West Siberia boreal zone. Contemp. Probl. Ecol. 2011, 4, 475-486. [CrossRef]

52. Dvornikov, Y.; Vasenev, V.; Romzaykina, O.; Grigorieva, V.; Litvinov, Y.; Gorbov, S.; Dolgikh, A.; Korneykova, M.; Gosse, D. Projecting the urbanization effect on soil organic carbon stocks in polar and steppe areas of European Russia by remote sensing. Geoderma 2021, 399, 115039. [CrossRef]

53. Wara, M.; Victor, D.G. A realistic policy on international carbon offsets. Program. Energy Sustain. Dev. Work. Pap. 2008, 74, 1-24.

54. Yu, J.; Mallory, M.L. Carbon price interaction between allocated permits and generated offsets. Oper. Res. 2017, 20, 671-700. [CrossRef]

55. Mack, M.C.; Walker, X.J.; Johnstone, J.F.; Alexander, H.D.; Melvin, A.M.; Jean, M.; Miller, S.N. Carbon loss from boreal forest wildfires offset by increased dominance of deciduous trees. Science 2021, 372, 280-283. [CrossRef]

56. Bumpus, A.G. The matter of carbon: Understanding the materiality of $\mathrm{tCO}_{2} \mathrm{e}$ in Carbon Offsets. Antipode 2011, 43, 612-638. [CrossRef]

57. Tsai, W.-H. Carbon emission reduction-Carbon tax, carbon trading, and carbon offset. Energies 2020, 13, 6128. [CrossRef]

58. Van Kooten, G.C.; Johnston, C.M. The economics of forest carbon offsets. Annu. Rev. Resour. Econ. 2016, 8, 227-246. [CrossRef]

59. Watt, R. The fantasy of carbon offsetting. Environ. Politi. 2021, 30, 1-20. [CrossRef] 